$\begin{array}{llllllllll}\mathrm{M} & \mathbb{A} & \mathrm{T} & \mathrm{E} & \mathrm{R} & \mathrm{I} & \overline{\mathrm{A}} & \mathrm{E} & \mathrm{Y}\end{array}$

Marek Kazimierz Kamiński

Instytut Historii im. Tadeusza Manteuffla PAN

\title{
Czechosłowacja w obliczu dyktatu mocarstw zachodnich w 1938 r. w świetle depesz Jana Masaryka z Londynu
}

Zarys treści: Rok 1938 był przełomowy dla bezpieczeństwa Czechosłowacji oraz całej Europy. Rozsypywał się porządek wersalski. Niemcy, przy milczącej zgodzie państw b. Ententy, uczyniły kolejny krok na drodze do wojny. Będący wówczas w Londynie Jan Masaryk obserwował działania rządu brytyjskiego i raportował o jego stanowisku do Pragi. Najważniejszym zadaniem było wysądowanie, jakie stanowisko zajmie Londyn w chwili, gdy dojdzie do bezpośredniej konfrontacji z III Rzeszą, coraz umiejętniej grającą kartą Niemców sudeckich.

Outline of content: The year 1938 was a turning point for the security both of Czechoslovakia and all Europe. The Versailles order was collapsing. Germany, with the silent concord of the former Entente states, made the first step towards war. Jan Masaryk, who at that time was in London, observed the moves of the British Cabinet and reported to Prague. His most important task was to sound out London's stance at the moment of direct confrontation with the Third Reich which increasingly skilfully was playing the card of the Sudeten Germans.

Słowa kluczowe: Czechosłowacja w okresie międzywojennym, rozbiór Czechosłowacji 1938, Niemcy w Czechosłowacji, stosunki brytyjsko-czechosłowackie, Jan Masaryk

Keywords: interwar Czechoslovakia, partition of Czechoslovakia 1938, Germans in Czechoslovakia, British-Czechoslovakian relations, Jan Masaryk

Załamanie się państwa czechosłowackiego w 1938 r. stanowiło bardzo poważne niebezpieczeństwo dla porządku europejskiego, ustanowionego przez zwycięskie państwa Ententy na konferencji w Wersalu w pierwszej połowie 1919 r. Głównym przegranym były Niemcy, obarczone odpowiedzialnością za wybuch wielkiej wojny. Wśród nowo powstałych państw znalazła się między innymi Czechosłowacja, zamieszkała nie tylko przez ludność czeską i słowacką, ale również niemiecką, 
pod względem liczebności drugą z kolei. Praktycznie więc mocarstwa zachodnie powołały do życia twór państwowy w swym kształcie niedoskonały, który prędzej czy później mógł być narażony na stanie się ofiarą ekspansjonizmu ze strony sąsiednich Niemiec. O tym nie pomyśleli twórcy ładu wersalskiego, beztrosko odcinając ludność niemiecką od jej głównego skupiska w Niemczech. Państwem czechosłowackim po wielkiej wojnie rządziła tzw. grupa Hradu, na czele z prezydentem Tomašem Garrigue Masarykiem. Nowym prezydentem w grudniu $1935 \mathrm{r}$. został Edvard Beneš, który w związku z tym ustąpił ze stanowiska czechosłowackiego ministra spraw zagranicznych. Syn Tomaša Masaryka Jan dzięki poparciu ojca został mianowany w 1925 r. czechosłowackim posłem w Londynie. Zajął więc eksponowane miejsce w czechosłowackiej dyplomacji.

Tymczasem od 1937 r. coraz bardziej narastało zagrożenie dla Czechosłowacji ze strony hitlerowskich Niemiec. W depeszy z Londynu z 5 listopada 1937 r. Jan Masaryk donosił centrali, że w partii nazistowskiej, jak również w niemieckich kręgach wojskowych rozpatrywane są plany wojenne przeciwko Czechosłowacji. Masaryk był zdania, że ich zwolennikom potrzebne jest stworzenie „atmosfery rewolucyjnej, która umożliwiłaby aktywne wystąpienie wobec polityki praskiego rządu”. Czynniki niemieckie natomiast uważały, że „konflikt z Czechosłowacją stanie się któregoś dnia nieodwracalny". 2 grudnia $1937 \mathrm{r}$. Masaryk został przyjęty na audiencji przez francuskiego premiera Camille'a Chautemps'a i francuskiego ministra spraw zagranicznych Yvona Delbosa. Obaj politycy zapewnili swojego rozmówcę, że „Czechosłowacja nie ma się czego obawiać i że o jakiejś «wolnej ręce» w Europie Środkowej nie może być mowy”. Masaryk usłyszał też, że „co się tyczy Europy Środkowej i Czechosłowacji, nie nastąpiła żadna zmiana w polityce angielskiej”. Wielka Brytania stała na stanowisku, że nie może z powodów wewnątrzpolitycznych podejmować z góry konkretnych zobowiązań, ale integralność Czechosłowacji uznawała za warunek niezbędny dla Europy Środkowej ${ }^{1}$.

6 grudnia 1937 r. brytyjski minister spraw zagranicznych Anthony Eden utrzymywał w rozmowie z Masarykiem, że o jakiejś napaści na Czechosłowację lub Austrię nie może na razie być mowy. Hitler oświadczył, że „nie ma zamiaru mieszać się w wewnętrzne sprawy praskie”. Pełne obłudy słowa kanclerza Rzeszy miały wkrótce udowodnić Europie, iż Hitlerowi nie można ufać. Pozostawała kwestia francusko-sowieckiego układu sojuszniczego z 1935 r. Strona brytyjska oświadczyła, że nie ma zastrzeżeń do francusko-sowieckiego układu politycznego, ale nie uważa, by Rosja posiadała odpowiednie kwalifikacje do występowania w roli alianta broniącego Czechosłowacji przed ekspansją niemiecką, biorąc pod uwagę to, co „się dzieje od roku w Rosji”. Eden miał na myśli eskalację terroru ze strony Stalina wobec wszystkich warstw społecznych Związku Sowieckiego, na niebywałą skalę. Tymczasem okazało się, że represje sowieckiego dyktatora nie osłabiały Związku Sowieckiego, ale wręcz go wzmacniały i czyniły gotowym do aktywnego udziału

1 J. Masaryk, Depeše z Londýna 1938, k vydání připravila Věra Olivová, Praha 1996, s. 38-42. 
w międzynarodowych rozgrywkach, oczywiście, kosztem słabszych państw regionu Europy Środkowo-Wschodniej².

W telegramie z 24 lutego 1938 r. Masaryk informował centralę: „mówiłem z kilkoma członkami gabinetu, którzy mnie zapewniali, że jakiekolwiek obawy są zbyteczne, że kurs antyczechosłowacki nie istnieje i że napaść na Czechosłowację miałaby całkiem inne następstwa niż pogwałcenie suwerenności Austrii”. „Z kręgów opozycji [w Wielkiej Brytanii] otrzymałem robiące wrażenie wyrazy przyjaźni i ochoty udzielenia pomocy - informował Masaryk. - Niestety nie mogą obietnice pomocy ze strony opozycji pomóc i muszę szukać jej u konserwatystów”. „Bardzo dobrze - kontynuował - że generał Ludwik Krejči, naczelnik sztabu głównego, w sposób jasny przemówił”. „Musimy - radził Masaryk - w ogóle trochę pokazać zęby. Jest potrzeba, aby Anglicy zrozumieli, że nasza cierpliwość nie jest bez dna i że byśmy się bronili, gdybyśmy zostali napadnięci”. „Mam nadzieję również depeszował - że prezydent republiki w krótkim czasie wyda jakieś oświadczenie". Dalej pisał: „Słowo we właściwym czasie od dr. Beneša - szefa ostatniego państwa na wschód od Renu, które się dumnie przyznaje do demokracji, może nam niezmiernie pomóc”. Masaryk wyrażał przekonanie, iż nadeszła chwila „właściwa dla zwiększenia czechosłowackiej działalności propagandowej w Wielkiej Brytanii”. Nie obawiam się o ostateczny wynik naszej dobrej sprawy, jeśli będzie w kraju jednolita polityka przyznająca się do demokracji i gotowa do ponoszenia ofiar na jej rzecz” - twierdził. „Chwila jest niezmiernie poważna - dodawał czechosłowacki polityk - i od wszelakich koalicyjnych żarcików należałoby odstąpić”’

Masaryk nawoływał więc do konsolidacji czechosłowackich sił politycznych w kraju celem przeciwstawienia się niemieckiemu ekspansjonizmowi. Popełniał jednak błąd, sądząc, że będzie można liczyć na solidarność mocarstw zachodnich z państwem czechosłowackim ze względu na ich system demokratyczny, analogiczny do istniejącego w Czechosłowacji. Błędne rachuby na pomocy tych samych formacji ustrojowych już wkrótce dały o sobie znać, przynosząc stronie czechosłowackiej rozczarowanie. 24 lutego 1938 r. Masaryk informował centralę, że obecne oficjalne stanowisko rządu brytyjskiego zawiera „do niczego niezobowiązujące zapewnienie stałych bardzo przyjaznych uczuć do narodu czechosłowackiego”. Nawiasem mówiąc, nie istniał naród czechosłowacki, lecz dwa odrębne narody: czeski i słowacki. Ponadto Masaryk głosił, że „Anglia ma w stosunku do Czechosłowacji jedynie ogólne zobowiązania wynikające z Paktu Ligi Narodów”. Czechosłowacki poseł twierdził też, że „Anglia jest w pełni świadoma zobowiązań, które łączą Czechosłowację z innymi mocarstwami” oraz przypominał, że Czechosłowacja ma układ o wzajemnej pomocy z Francją, który Francję zobowiązuje do przyjścia Czechosłowacji z pomocą w przypadku niesprowokowanego ataku. „Anglia głosi, że jest tego świadoma" - zwracał uwagę Masaryk. Wobec takiego a nie innego układu

\footnotetext{
2 Ibidem, s. 43-44.

3 Ibidem, s. 45-48.
} 
sił stronie czechosłowackiej pozostawało niezwykle trudne zadanie skłonienia Wielkiej Brytanii do uzyskania od niej „zapewnienia, że nie zostawi Czechosłowacji na lodzie, gdyby Francja sprzeciwiła się niemieckiemu atakowi na Czechosłowację"4.

W depeszy z 1 marca 1938 r. Masaryk stwierdzał: „doradzam zwrócić uwagę naszej prasy, aby obecnie nie naciskała na Anglię, aby ta zajęła jasne stanowisko w kwestii gwarancji dla Czechosłowacji, by problem ten nie stał się przedmiotem partyjnej walki między tutejszym rządem [brytyjskim] a labourzystowską opozycją". 4 marca 1938 r. Masaryk został przyjęty przez nowego brytyjskiego ministra spraw zagranicznych Edwarda Halifaxa, który przywitał czechosłowackiego posła serdecznie, jak starego znajomego. Przypomniał też wypowiedź poprzedniego brytyjskiego ministra spraw zagranicznych Anthony'ego Edena, który uważał, że im więcej wyjdą Czesi naprzeciw postulatom swoich Niemców, tym silniejsza będzie ich pozycja międzynarodowa. Twierdzenie to nie spotkało się $\mathrm{z}$ aprobatą czechosłowackiego posła, który nazwał je starą śpiewką. Halifax zaś zwrócił uwagę swego interlokutora na bardzo niepomyślne pod względem geograficznym położenie Czechosłowacji. Tymczasem Masaryk uważał, że gra toczy się o przekonanie Zachodu co do „doniosłości Czechosłowacji jako ostatniej wyspy demokracji”. Poseł czechosłowacki wyrażał przekonanie, że uda się zapobiec wojnie, „jeśli będziemy zgodni i właśnie tą zgodnością przekonamy zachodnie demokracje o swej lojalności gdyby doszło do najgorszego ${ }^{5}$.

13 marca 1938 r. niemiecki minister spraw zagranicznych Joachim von Ribbentrop zapewniał kilkakrotnie brytyjskiego ministra Halifaxa, że Niemcy nie mają agresywnych zamiarów wobec Czechosłowacji. Poinformowany o tych enuncjacjach, Masaryk oświadczył Halifaxowi, że nie daje wiary tym zapewnieniom i wyraził przekonanie, iż Niemcy postąpią tak, jak będzie im wygodnie. Halifax podzielał opinię Masaryka, z tym że odnosił wrażenie, iż Niemcom w bliskiej przyszłości nie będzie zależało na przeprowadzeniu ataku na Czechosłowację. Zaangażowanie w anszlus Austrii zdawało się odsuwać możliwość ataku na państwo czechosłowackie na późniejszy nieco termin. Halifax podpytywał Masaryka, jakie znaczenie przypisuje zapewnieniom Hermanna Göringa, że Niemcy nie poczynią żadnych kroków wymierzonych w Czechosłowację. Masaryk odpowiedział, że chwilowo jest to prawda, ponieważ będą potrzebować ,jakiegoś czasu na strawienie Austrii”. Halifax pod wrażeniem słów Masaryka przejawił ochotę udzielenia pomocy stronie czechosłowackiej. Przyznał się jednak do tego, że nie wie, co należałoby uczynić w tym względzie. Masaryk podsunął Halifaxowi myśl potraktowania słów Göringa jako oficjalnej wypowiedzi niemieckiej. Na pytanie Halifaxa, co by się stało, gdyby Niemcy sprowokowali niepokoje w Czechosłowacji, a następnie wtargnęli do niej, Masaryk odpowiedział: strzelalibyśmy ${ }^{6}$.

\footnotetext{
${ }^{4}$ Ibidem, s. 48-52.

5 Ibidem, s. 53-55.

${ }^{6}$ Ibidem, s. 58-60.
} 
18 marca 1938 r. Masaryk odbył nieprzyjemną rozmowę z Orme Sargentem, sekretarzem Halifaxa. Sargent twierdził, że rząd brytyjski ze względu na opinię publiczną nie będzie mógł konkretnie opowiedzieć się po stronie Czechosłowacji, jeśli ta nie przyzna tzw. Niemcom sudeckim jakiś ustępstw, tak aby ich - jego zdaniem - uprawnione skargi zostały załatwione pozytywnie. Masaryk doradzał centrali, aby rząd czechosłowacki „przyspieszył swoje własne konstruktywne propozycje, dotyczące uporządkowania spraw naszych Niemców”. Poseł czechosłowacki przestrzegał, iż niezmiernie niebezpieczne jest mówienie obecnie o plebiscycie, który w wypadku Austrii Hitler wykorzystał do wtargnięcia do tego kraju. Masaryk zwracał uwagę, że angielska opinia publiczna staje po stronie Czechosłowacji, „ale nie wierzy, że robimy wszystko, co w naszej mocy dla naszych Niemców”. Charakterystyczne dla brytyjskiej postawy było stanowisko ministra wojny Lesliego Hore-Belishy, który w sposób otwarty oświadczył dziennikarzom amerykańskim 28 kwietnia 1938 r., że los Czechosłowacji jest przypieczętowany i nic jej nie uchroni przed niemieckim panowaniem, osiągalnym nawet bez bezpośredniej inwazji niemieckiej. Zdaniem Brytyjczyka zanim państwa demokratyczne zdecydują się na stawienie oporu, „mniejszości w Czechosłowacji i gdzie indziej będą wcielone do niemieckiej Rzeszy". Podczas spotkania 5 kwietnia 1938 r. Masaryka z brytyjskim podsekretarzem stanu Aleksandrem Cadoganem, brytyjski dyplomata oświadczył, że gdyby strona czechosłowacka potrzebowała od przypadku do przypadku pomocy brytyjskiej, to choć nie może dać żadnych zobowiązujących obietnic, zapewnia w imieniu Halifaxa, że uczyni wszystko, co będzie w granicach brytyjskich możliwości ${ }^{7}$.

Podczas wspomnianego spotkania Masaryka z Cadoganem 5 kwietnia 1938 r. brytyjski dyplomata mówił „o wielkiej nieufności w stosunku do Rosji i wątpliwości, czy Rosja mogłaby skutecznie interweniować poza swoimi granicami”. „Nie znaczy to - kontynuował Cadogan - że nie miałoby się politycznie z Rosją współpracować, przeciwnie - jest w interesie Czechosłowacji, aby stawiać Niemcom przed oczyma niebezpieczeństwo rosyjskiej ingerencji, ponieważ pomimo wszelkich zapewnień Niemcy boją się Rosji”. Przywódca partii Niemców sudeckich Konrad Henlein domagał się autonomii dla ziem zamieszkałych przez ludność niemiecką na terytorium państwa czechosłowackiego. W telegramie z 14 maja 1938 r. Masaryk pozwolił sobie na następującą refleksję: „wodziliśmy Niemców za nos przez osiemnaście lat niespełnionych obietnic”, co spowodowało „radykalizację partii Niemców sudeckich, która jest w większości za anschlussem”. „Mam definitywne wrażenie - telegrafował Masaryk 14 maja 1938 r. - że Henleinowi w ogóle nie dogadza przyłączenie ziem państwa czechosłowackiego do Rzeszy Niemieckiej". Natomiast układ czechosłowacko-sowiecki Henlein uważał za szkodliwy dla pokoju europejskiego, ale uznawał rolę odgrywaną przez ZSRR w polityce międzynarodowej.

\footnotetext{
7 Ibidem, s. 61-72.
} 
Halifax wskazywał, że rząd angielski jest rozczarowany słabym postępem rokowań prowadzonych przez stronę czechosłowacką i powtarzał, że konieczne są szybkie rokowania i daleko idące koncesje na rzecz ludności niemieckiej. Masaryk próbował usprawiedliwiać stronę czechosłowacką tym, iż opinia publiczna Czechosłowacji nie jest wychowana w mentalności wielkich koncesji. Halifax ostrzegał, że postępowanie władz czechosłowackich budzi niezadowolenie mocarstw zachodnich ${ }^{8}$.

29 czerwca 1938 r. na posiedzeniu gabinetu brytyjskiego Chamberlain otwarcie obwinił prezydenta Beneša i rząd czechosłowacki o umyślne opóźnianie negocjacji w sprawie rozwiązania problemu Niemców sudeckich. Krążyły też podejrzenia, że rząd czechosłowacki nie chce porozumieć się z Niemcami sudeckimi i nie rokuje $\mathrm{z}$ nimi jak równy z równym. Mówiono też, iż Rosja naciska na Czechosłowację, by ta sprowokowała wojnę, i że Beneš życzy sobie wojny. Masaryk nazywał osoby głoszące nieprzyjemne dla prezydenta Czechosłowacji twierdzenia propagandystami. 26 sierpnia 1938 r. Halifax zadał pytanie francuskiemu radcy poselstwa francuskiego w Londynie Rogerowi Cambonowi, co Francja sądzi o sytuacji i jak by się zachowała, gdyby Hitler napadł na Czechosłowację. W odpowiedzi usłyszał, że Francja widzi sytuację czarno i nie wyklucza żadnej niespodzianki. W wypadku napaści na Czechosłowację minie kilka dni, zanim francuska opinia publiczna podejmie decyzję. Ostatecznie rozstrzygający będzie fakt, że Francja jest związana układami sojuszniczymi. Halifax zgodził się, że sytuacja jest skrajnie poważna. Był świadom tego, że żadne ostrzeżenia nie pomogą, jeśli Hitler będzie chciał napaść na Czechosłowację. Cambon przypomniał też, że we Francji cała lewica jest zwolenniczką pomocy dla Republiki Czechosłowackiej. Zwrócił też uwagę, że duża część prawicy, mając interesy egoistyczne, głównie finansowe, pragnie pokoju za wszelką cenę?.

Tymczasem w Czechosłowacji szerzono wieści, że w kraju przygotowywany jest bunt przeciwko Benešowi. Zdaniem Masaryka byłoby dobrze oficjalnie zwrócić uwagę na lojalność armii, jej gotowość do działań obronnych oraz jedność czechosłowackiego społeczeństwa. Poseł czechosłowacki ostrzegał też przed szykującymi zamachy agentami prowokatorami. Tajny informator donosił 14 września 1938 r. Masarykowi, że Chamberlain nie jest przekonany, że Francja i ZSRR od razu ruszą z pomocą Czechosłowacji. Chamberlain nie wykluczał, że Hitler wtargnie na ziemie państwa czechosłowackiego, obsadzi ziemie niemiecką, a następnie ogłosi rozejm i wieczny pokój. 14 września 1938 r. podczas rozmowy francuskiego ministra spraw zagranicznych Georges’a Bonneta z brytyjskim posłem w Paryżu Erikiem Phippsem Bonnet oświadczył, że trzeba utrzymać pokój także za cenę Czechosłowacji, bowiem Francja nie jest przygotowana do wojny i nie chce walczyć za Czechosłowację. Informator Masaryka radził stronie czechosłowackiej od razu przygotowywać się do wojny, gdyż tylko w takiej sytuacji może liczyć na pomoc

\footnotetext{
8 Ibidem, s. 76-81.

${ }^{9}$ Ibidem, s. 85-89.
} 
Francji i Wielkiej Brytanii. Egipski ambasador, który wrócił właśnie z Berlina, usłyszał od niemieckiego ministra spraw zagranicznych Ribbentropa, że Hitler obecnie zdecydował się załatwić sprawę sudecką i nic na świecie nie jest w stanie go od tego odwieść. Jeśli uda się to załatwić drogą pokojową - to dobrze, w przeciwnym wypadku pozostaje wojna. Ribbentrop oświadczył, że Wielka Brytania nie powinna się do tego mieszać i problem załatwią same Niemcy. Masaryk w notatce do Beneša z 14 września 1938 r. stwierdził, że strona czechosłowacka nie ma zaufania do żadnych gwarancji Hitlera ${ }^{10}$.

20 września 1938 r. Masaryk informował centralę, że Wielka Brytania i Francja proponują daleko idące zmiany granic państwa czechosłowackiego. Propozycja została złożona $\mathrm{w}$ formie faktu dokonanego, mimo iż dzień wcześniej strona czechosłowacka prosiła mocarstwa o uprzednie konsultacje. Masaryk nie wahał się nazwać postępowanie mocarstw zachodnich jedynym w swoim rodzaju „zezwierzęceniem". Uważał też, że gdyby rokowano o przyjęciu propozycji mocarstw zachodnich, należałoby starać się uzyskać gwarancje mocarstw, włącznie z Związkiem Sowieckim, ale z pominięciem sąsiadów. Masaryk dowiedział się, że francuski sztab generalny oświadczył, iż jest zupełnie nieprzygotowany do działań wojennych, przede wszystkim w zakresie lotnictwa, a wojna europejska byłaby klęską. „Z trudem mogę w to uwierzyć" - skomentował tę wiadomość Masaryk. Czechosłowacki poseł usłyszał od Halifaxa 25 września 1938 r., że brytyjski premier Chamberlain do tej pory jest przekonany, że Hitler jest wiarygodny (działa bona fide) i że gdy dostanie ziemie sudeckie, da Europie spokój na zawsze. Brytyjska ocena sytuacji wprawiła Masaryka w zdumienie. Nazwał ją kryminalną naiwnością. Halifax przyznał, że Chamberlain odgrywał "rolę listonosza” między brytyjskim premierem a kanclerzem Rzeszy Hitlerem ${ }^{11}$.

Problem ziem zamieszkałych przez ludność niemiecką w państwie czechosłowackim, czyli tak zwanych Niemców sudeckich, stał się przyczyną klęski Czechosłowacji w 1938 r. Niemcy mieli prawo domagać się utworzenia własnego państwa zgodnie z zasadą samostanowienia narodów. W 1921 r. Niemcy stanowili 23,4\% ludności kraju i byli drugim pod względem liczebności narodem w republice. Ustalając granice międzypaństwowe, zwycięskie mocarstwa Ententy mogły zapobiec niepotrzebnemu konfliktowi, przez który Europa w 1938 r. znalazła się nagle w przededniu kolejnej wojny światowej. Nie uczyniły tego jednak, gdyż zabrakło im wyobraźni politycznej. Za to wszystko zapłaciła Czechosłowacja.

\footnotetext{
10 Ibidem, s. 96-97.

11 Ibidem, s. 98-102.
} 


\section{Czechoslovakia Facing the Dictate of the Western Powers in 1938 in the Light of Jan Masaryk's Telegrams from London}

\section{Abstract}

The problem of lands inhabited by German populations within the Czechoslovak state, called the Sudeten Germans, caused the fall of Czechoslovakia in 1938. The Germans had the right to demand - under the principle of self-determination- the creation of an independent state. In 1921 there was in Czechoslovakia a substantial German minority of 23.4 percent, making it the second largest nationality in the republic. When determining new borderlines, the victorious powers of the Entente were able to prevent an unnecessary conflict which pushed Europe in 1938 on the threshold of a new world war. But they missed the opportunity for the lack of their political imagination. And it was Czechoslovakia who paid dearly for it.

\section{Чехословакия перед лицом диктата западных держав в 1938 г. в свете депеш Я. Масарика из Лондона}

\section{Аннотация}

Проблема земель, населенных немцами в Чехословацком государстве, то есть т. н. Судетских немцев, стала причиной поражения Чехословакии в 1938 г. Немцы имели право требовать создать собственное государство, согласно принципу самоопределения наций. В 1921 г. немцы составляли 23,4 \% населения страны и были вторым по численности народом республики. Устанавливая межгосударственные границы, победившие державы Антанты были властны предотвратить ненужный конфликт, который стал причиной того, что Европа вдруг в 1938 г. оказалась на пороге очередной мировой войны. Однако они не сделали этого, так как им не хватило политического воображения. За все это поплатилась Чехословакия.

Marek Kazimierz Kamiński, prof. dr hab., pracownik naukowy Instytutu Historii PAN; specjalizuje się w historii Polski i historii powszechnej najnowszej oraz historii stosunków międzynarodowych i jest autorem wielu publikacji z zakresu problematyki polsko-czechosłowackiej; były redaktor naczelny „Studiów z Dziejów Rosji i Europy Środkowo-Wschodniej”.

Marek Kazimierz Kamiński, Prof. Dr. hab., he works at the Institute of History of the Polish Academy of Sciences; he specialises in the $20^{\text {th }}$-century history of Poland and universal history and the history of international relations; he is the author of numerous publications on Polish-Czechoslovak relations and issues; the former editor-in-chief of the periodical Studies in the History of Russia and Central-Eastern Europe. 